\title{
ON A FOURTH COLLECTION OF BIRDS MADE BY MR. GEORGE FORREST IN NORTH-WESTERN YUNNAN
}

\section{BY LORD ROTHSCHILD, F.R.S.}

$\mathrm{T}$ HE collection is rather smaller than the former ones owing to a bad season, interference with freedom of travel owing to bandits, and other similar causes. It appears to have been made also at the lower and intermediate ranges for the most part, as it almost entirely consists of the more tropical species. There are a good number not sent in previous collections. These have the first quotation noted, while all those sent in former collections have not.

\section{Arboricola torqueola (Valenc.).}

Perdix torqueola Valenciennes, Dict. Scienc. Nat. vol, xxxviii, p. 435 (1825) (Bengal).

The $q$ has the breast much darker olive-brown than any of my Indian examples, but as the $\delta$ agrees perfectly I do not venture to separate the Yunnan bird on the evidence of a single + .

$1 \hat{\sigma}, 1$ ㅇ hills N. of Tengyueh, 8,000 ft. (scrub and cane brakes), Aug. 1924. (Iris orange-red; naked space round eye orange-crimson; bill dark reddishbrown, tip paler; feet deep brownish-red, claws orange-brown.)

\section{Bambusicola fytchii fytchii Anders.}

3 oิ $\widehat{0}, 1$ ㅇ hills N. of Tengyueh, 5,000-7,000 ft. (thickets), July-Aug. 1924. (Iris brownish-yellow; bill upper mandible black-brown, lower dull brown; feet and legs dull grey, claws brown.)

\section{Gennaeus nycthemerus (Linn.).}

Phasianus nycthemerus Linnaeus, Syst. Nat. edit. x, pt. i, p. 272, No. 6 (1758) (China ex Albin).

Forrest sent 1 ઈิ, 2 우우, which are very welcome, as wild shot birds are very rare in collections.

1 ô, 2 우우 hills N.W. of Tengyueh, 8,000-10,000 ft. in forests, Aug. 1924. (Iris golden-yellow, paler in 우; bill dull brown with dark-brown base of upper mandible in $\widehat{o}$, dark brown upper and light brown under mandible in $o$; feet and legs crimson, claws flesh-pink.)

\section{Chrysolophus amherstiae (Leadb.).}

1 fledgling \%, hills N.W. of Tengyueh, 9,000 ft. (forests), Aug. 1924.

\section{Porzana fusca erythrothorax (Temm. \& Schleg.).}

Gallinula erythrothorax Temminck \& Schlegel, in Siebold's Faun Jap. Aves, p. 121, pl. lxxviii (1849) (Japan).

1 ô, 1 ㅇ Tengyueh Valley, 5,500 ft. (swamps and rice-fields), June 1924. (Iris deep orange-crimson; naked area round eye crimson ; feet deep orangered, claws brown; bill brown-black.) 


\section{Rostratula benghalensis benghalensis (Linn.).}

The single $o$ sent is abnormal, the hindneck being entirely black and the foreneck and chest much blacker than usual.

1 우 Tengyueh, 5,500 ft. (rice-fields), Dec. 1924.

7. Gallinago solitaria Hodgs.

Gallinago solitaria Hodgson, Gleanings in Science, vol. iii, p. 238 (1831) (Nepal).

1 ? hills $\mathrm{N}$. of Tengyueh, 6,000 ft. (Alpine marshes), Dec. 1924.

\section{Tringa ocrophus Linn.}

2 우우 Tengyueh Valley, 6,000-7,000 ft. (rice-fields and marshes), Nov.Dec. 1924.

\section{Tringa nebularia (Gunn.).}

1 ㅇ? ? Tengyueh, 6,000 ft., Dec. 1924.

\section{Himantopus himantopus himantopus (Linn.).}

Charadrius himantopus Linnaeus, Syst. Nat. edit. x, pt. i, p. 151 (1758) (S. Europe).

1 ? (in very worn plumage) Tengyueh Valley, 5,300 ft. (rice-fields), Sept. 1924.

\section{Sarcogrammus indicus atronuchalis (Blyth).}

1 to Tengyueh Valley, 6,000-7,000 ft. (rice-fields and marshes), Dec. 1924.

12. Microsarcops cinereus (Blyth). Dec. 1924 .

2 oै $\widehat{0}, 1$ ㅇ Tengyueh Valley, 6,000-7,000 ft. (rice-fields and marshes),

\section{Charadrius dominicus fulvus $\mathrm{Gm}$.}

2 ? Tengyueh, 5,500 ft. (rice-fields), Dec. 1924.

14. Charadrius placidus Gray.

2 우우, Tengyueh Valley, 5,500 ft., June 1924; 1 Shweli Valley, 6,000 ft., Oct. 1924.

15. Sphenurus sphenurus yunnanensis La Touche.

1 t hills N. of Tengyueh, 8,000 ft., July 1924 ; 2 우오 Shweli Valley, 7,900 ft., Dec. 1924 ; 2 우오 Shweli-Salwin Divide, 7,000-9,000 ft., July 1924.

16. Streptopelia chinensis forresti subsp. nov.

This form from N.W. Yunnan is a mountain form and only a single $\widehat{\alpha}$ was sent by Forrest in his first collection, and was erroneously identified by me as chinensis vacillans Hart., which is a bird of the plains and appears to be only known so far from Mengtz.

This new form is nearest to chinensis suratensis (Gm.).

$\widehat{o}$ ad. differs from c. suratensis in the greyer, less brownish head and neck, 
in the less distinct rusty buff markings and paler ground colour of the back and interscapulium; in the absence on the upper large and small wing-coverts of the vinaceous patches, which are replaced by irregular more or less obsolete rusty markings ; by the narrower central black stripes on the upper wing-coverts ; by the brighter blue-grey of the edge of the wing and outer coverts; by the darker breast; and by the buff, not whitish or whitish buff under tail-coverts. The young bird is almost uniform greyish olive-brown above and grey saturated with brown and yellowish rusty below.

1 ô hills round Tengyueh, 5,000-7,000 ft., July 1924 (type) ; (bill brownblack ; feet crimson ; iris ereamy yellow); 1 ô Tengyueh, 5,000-7,000 ft., Nov. $1924 ; 2$ ธิธิ, 1 ô juv. Tengyueh Valley, 6,000 ft., July 1924.

\section{Streptopelia orientalis orientalis (Lath.).}

2 우우 hills N. of Tengyueh, 6,000 ft., July 1924.

\section{Columba hodgsoni Vig.}

1 t hills N. of Tengyueh, 7,000 ft., Dec. 1924; 1 \& Shweli-Salwin Divide, $8,000 \mathrm{ft}$., Dec. 1924 .

\section{Phalacrocorax javanicus (Horsf.).}

Carbo javanicus Horsfield, Trans. Linn. Soc. Lond. vol. xiii, p. 197 (1822) (Java).

1 ô ad. Tengyueh Valley, 5,000-6,000 ft., June 1924; 1 우 jun. Tengyueh Valley, 6,000 ft., Oct. 1924.

20. Nyroca fuligula (Linn.).

Anas fuligula Linnaeus, Syst. Nat, edit. x, pt. i, p. 128, No. 39 (1758) (European seas).

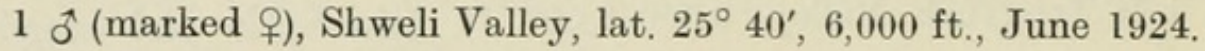

\section{Butorides striatus amurensis Schrenck.}

Ardea (Butorides) virescens var. amurensis, Schrenck, Reis. Amur-Lande, vol. i, pt. ii, p. 441 (1860) (Amur).

† imm. hills N.W. of Tengyueh, 7,000 ft., Aug. 1924.

22. Ardeola bacchus (Bpt.).

1 ô Shweli Valley, 7,000 ft., Dec. 1924; 1 o Shweli-Salwin Divide, 6,000 ft., Nov. 1924.

\section{Bubulcus ibis coromandus (Bodd.).}

1 우 ad. (breeding plumage) Tengyueh Valley, 5,300 ft., June 1924 ; 3 우우 (non-breeding plumage) ditto, 6,000 ft., Aug. 1924.

\section{Egretta garzetta garzetta (Linn.).}

Ardea garzetta Linnaeus, Syst. Nat. edit. xii, pt. i, p. 237, No. 13 (1766) (habitat in Oriente).

1 ô, 1 우 Tengyueh Valley, 5,300 ft., June 1924.

\section{Circus cyaneus cyaneus (Linn.).}

1 t hills N. of Tengyueh, 8,000 ft., Dec. 1924. 
26. Circus melanoleucus (Forst.).

1 ơ Shweli Valley, 6,000-9,000 ft., Dec. 1924 ; 1 Tengyueh Valley, 5, $300 \mathrm{ft}$., Sept. 1924.

27. Falco tinnunculus tinnunculus Linn.

Falco tinnunculus Linnaeus, Syst. Nat. edit. x, vol. i, p. 90, No. 15 (1758) (Europe).

1 ô, 2 우우 Shweli Valley, 6,000-9,000 ft., Dec. 1924; 1 ô Shweli-Salwin Divide, 7,000-8,000 ft., Dec. 1924; 1 q hills round Tengyueh, 6,000 ft., Dec. 1924.

28. Falco tinnunculus interstinctus (McClell.).

1 ô juv., 1 ㅇ ad. Shweli Valley, 6,000-9,000 ft., Nov.-Dec. 1924.

29. Strix aluco harterti (La Touche).

Again only a single example was obtained, and it is as yet very doubtful if $S$. $a$. harterti and $a$. nivicola are identical or not.

1 ô hills N.W. of Tengyueh, 9,000 ft., Aug. 1924. (Iris purple-black; bill blue-grey, tip yellow ; claws brown.)

\section{Otus bakkamoena glabripes (Swinh.).}

$1 \widehat{\delta}, 1$ ㅇ ad., 1 ô, 1 우 juv. Shweli-Salwin Divide, 6,000-7,000 ft., May 1924.

\section{Cuculus sparverioides Vig.}

One $\delta$ is conspicuous by the strong wash of rufous on the breast.

1 §ै, 2 우 Tengyueh, 5,000-6,000 ft., June 1924; 1 ô juv., 1 우 hills N.W. of Tengyueh, 9,000 ft., Aug. 1924.

\section{Cuculus intermedius intermedius Vahl.}

$1 \hat{\jmath}, 1$ 오 (red phase) hills N.W. of Tengyueh, 7,000-8,000 ft., Oct. 1924 ; 1 ơ Tengyueh, 7,000 ft., May 1924; 1 의 (grey phase) Tengyueh Valley, 6,000 ft., June 1924.

\section{Cuculus canorus telephonus Heine.}

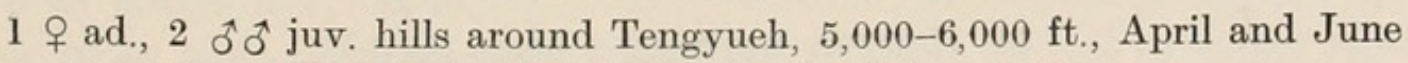
$1924 ; 1$ ડิ, 1 ㅇ ad. Tengyueh, 6,000-7,000 ft., April-May 1924.

\section{Cacomantis merulinus querulus Heine.}

$1 \hat{\sigma}$ ad. hills around Tengyueh, 6,000 ft., June $1924 ; 1$ ô juv. hills N.W. of Tengyueh, 8,000 ft., Oct. 1924.

35. Eudynamis honorata malayana Cab. \& Heine.

Of the 2 ơ ô sent, No. 5172 has a wing of $203 \mathrm{~mm}$., and No. 5040 of $207 \mathrm{~mm}$., so the difference from $h$. honorata with a wing of $194 \mathrm{~mm}$. holds good.

1 ๙ Tengyueh Valley, 5,000-6,000 ft., 1 ô hills round Tengyueh, 5,000$6,000 \mathrm{ft}$., June 1924 .

36. Centropus bengalensis bengalensis (Gm.).

$1 \hat{o}$ bills round Tengyueh, 8,000 ft., Aug. 1924. 
37. Pyrotrogon erythrocephalus yamakanensis (Rich.).

$1 \widehat{c}$ hills round Tengyueh, $9,000 \mathrm{ft}$, 1 ㅇ hills N. of Tengyueh, 9,000 ft., July $1924 ; 1$ ㅇ Shweli-Salwin Divide, $25^{\circ} 40^{\prime}$ N. lat., 9,000 ft., May 1924.

38. Dryobates semicoronatus omissus Rothsch.

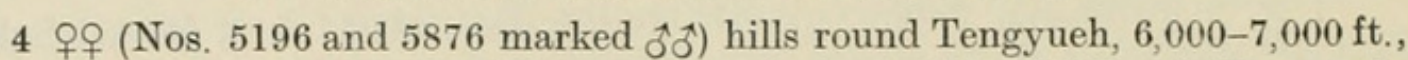
June and Dec. 1924; 2 우우 (No. 5433 marked $\sigma^{*}$ ) hills N.W. of Tengyueh, $8,000 \mathrm{ft}$., Sept. 1924; $1 \hat{\sigma}$ (labelled क) Tengyueh Valley, 6,000 ft., Oct. 1924; $1 \hat{\delta}, 1$ 우 (sexes reversed 5787 marked $q=\hat{\sigma} 5786$ marked $\hat{\sigma}=$ ) ) Shweli Valley, 6,000-9,000 ft., Dec. 1924; 1 ô, 1 오 Shweli-Salwin Divide, 7,000$9,000 \mathrm{ft}$., July and Oct. 1924 (No. 5432 marked $+=\delta^{\top}$ ).

39. Dryobates cabanisi cabanisi (Malh.).

1 ô, 2 우우 hills round Tengyueh, 7,000-9,000 ft., Dec. 1924.

40. Dryobates darjellensis (Blyth).

1 \% hills round Tengyueh, 7,000-9,000 ft., Dec. 1924.

41. Picus canus sordidior (Rippon).

2 ธึరో, 2 우우 Shweli Valley, 6,000-9,000 ft., Dec. 1924; 1 ㅇ Shweli-Salwin Divide, 7,000 ft., Oct. 1924 ; 1 ㅇ ad., 1 q juv. hills round Tengyueh, 6,000$9,000 \mathrm{ft}$., July and Dec. 1924.

42. Cyanops franklini franklini (Blyth).

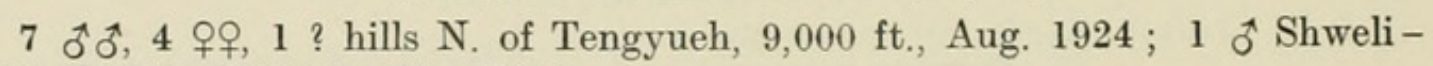
Salvin Divide, 9,000 ft., Dec. 1924.

\section{Alcedo atthis bengalensis $\mathrm{Gm}$.}

$1 \hat{\delta}$ ad. round Tengyueh, $6,000 \mathrm{ft}$., Dec. $1924 ; 1 \hat{\delta}$, ? juv. Tengyueh Valley, $5,300 \mathrm{ft}$., July 1924 .

44. Halcyon smyrnensis fusca (Bodd.).

1 ơ Tengyueh Valley, 6,000 ft., Dec. 1924; 1 ô Shweli Valley, 6,000 ft., Dec. 1924.

\section{Psittacula schisticeps finschi Hume.}

With the exception of No. 5517 all the adult $\sigma^{0} \sigma^{1}$ and the $q$ are in full moult.

5 oิ $\widehat{0}, 1$ ㅇ adult (No. 5517 freshly moulted), 3 우, ? juv., hills N.W. of Tengyueh, 7,000-8,000 ft., Sept.-Oct. $1924 ; 1$ ô, 2 우 juv., Shweli-Salwin Divide, $25^{\circ} 40^{\prime}$ N. lat., 6,000 ft., May 1924 .

\section{Coracias affinis McClell.}

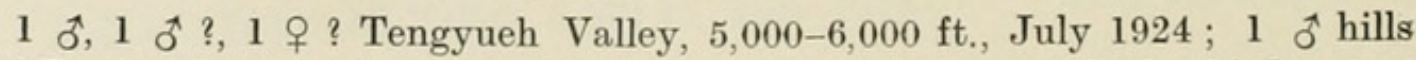
$\mathrm{N}$. of Tengyueh, $6,000 \mathrm{ft}$., July 1924 (all these 4 birds are much abraided); 1 t around Tengyueh, 6,000 ft., Dec. 1924; 1 ô Shweli Valley, 6,000 ft., Dec. 1924 (these 2 birds are in fresh plumage). 
47. Eurystomus orientalis calonyx Sharpe.

Eurystomus calonyx Sharpe, Proc. Zool. Soc. Lond. 1890, p. 551 (Nepal).

1 ô, 2 우 juv. hills N.W. of Tengyueh, 7,000 ft., July 1924.

48. Hirundo rustica gutturalis Scop.

1 ô, ? juv., 2 우 ad. Tengyueh Valley, 5,300 ft., June 1924.

\section{Tesia cyaniventer Hodgs.}

This time Mr. Forrest sent 3 young birds of this interesting little species.

Above dark olive, a yellowish olive superciliary line, and a broad black band behind eye. Below dark grey strongly washed with olive.

There is considerable confusion about the generic terms for this bird and the allied castaneo-coronata Burton. In vol. vii of the Catalogue of Birds, Dr. Sharpe places these 2 and a Javanese species in the genus Oligura Hodgson, although Tesia Hodgson is older. In the Handlist, vol. iv, p. 58, Dr. Sharpe separates the 2 birds, placing cyaniventer under Tesia and castaneo-coronata into Oligura, quoting Oates's Fauna of British India as his authority. Oates fixes the type of Tesia Hodgs. by "Subsequent Designation" as cyaniventer Hodgs. Hartert, in his Vögel de paläarktischen Fauna, reunites the two genera by placing castanea-coronata under Tesia. Outram Bangs has again separated castaneocoronata, generically replacing it in Oligura. As, however, I shall not have to deal with castaneo-coronata here, I shall say no more about the generic question, except that, as Oates fixed the type of Tesia as cyaniventer, whether castaneocoronata is congeneric or not, I am correct in putting cyaniventer in the genus Tesia.

$2 \widehat{ઠ} \widehat{o ̂}^{2}$ ? 1 우, ? juv. hills N. of Tengyueh, 8,000 ft., July 1924.

50. Spelaeornis kauriensis (Har.).

1 o hills N.W. of Tengyueh, 8,000 ft., Nov. 1924.

51. Pnoepyga squamata magnirostris subsp. nov.

o ad. similar to s. mutica, but more olive-brown, less rufous above, and the yellow spots more defined both on back and rump. The bill is longer and stouter; exposed culmen $11 \mathrm{~mm}$. (in s. mutica $8 \frac{1}{2} \mathrm{~mm}$.).

1 ㅇ (rufous form) Shweli Valley, 7,000 ft., Nov. 1924. (Iris black-brown ; bill, upper mandible dark brown, lower mandible yellow; feet dark greyish brown.) (Wing $63 \mathrm{~mm}$.)

\section{Enicurus maculatus guttatus Gould.}

$1 \hat{\jmath}$ hills round Tengyueh, $7,000 \mathrm{ft}$., Dec. $1924 ; 1$ ? ?, 1 ô ? juv., 1 ? hills N. of Tengyueh, 6,000-7,000 ft., July-Aug. 1924.

\section{Enicurus schistaceus Hodgs.}

1 ㅇ hills round Tengyueh, 8,000 ft., Nov. 1924.

\section{Phoenicurus frontalis sinae Hart.}

5 oิ $\widehat{o}$ ad. (Nos, 5760 and 5761 marked q errore!!) Shweli Valley, 7,000-8,000 ft., Nov.-Dec, 1924; 1 ㅇ hills round Tengyueh, 8,000 ft., Dec. 1924. 


\section{Phoenicurus auroreus leucopterus Blyth.}

1 đิ round Tengyueh, 7,000 ft., Dec. 1924.

\section{Tarsiger rufilatus practicus (Bangs \& Phill.).}

Our two $\delta^{t}$ from the former collections and the series from the Tsinling Mts. certainly agree with the authors' description, but the present example is practically indistinguishable from $r$. rufilatus; this confirms my former statement that $r$. practicus is a very poor subspecies indeed.

1 ô ad. (marked ㅇ) Shweli Valley, $800 \mathrm{ft}$., Dec. 1924.

\section{Notodela leucura leucura (Hodgs.).}

Muscisylvia leucura Hodgson, Proc. Zool. Soc. Lond. 1845, p. 27 (Nepal).

3 ? juv. hills N.W. of Tengyueh, 9,000 ft., Sept. 1924.

\section{Copsychus saularis saularis (Linn.).}

1 ऽิ, 2 우 ad., 2 우우 juv. Shweli-Salwin Divide, lat. $25^{\circ} 40^{\prime}$ N., 7,000-8,000

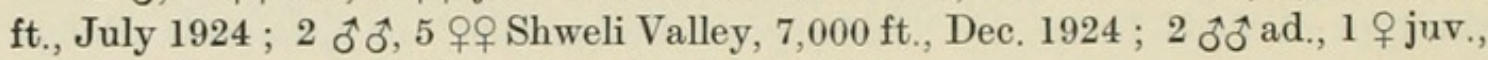
1 ơ juv. Tengyueh Valley, 6,000 ft., Sept. 1924.

\section{Oreicola ferrea haringtoni Hart.}

Hartert gives as sole distinction in the bird the shorter tail, and states that Colonel Harington discovered that the eggs of this form are darker blue and invariably without any markings, whereas in $f$. ferrea the eggs are clouded and spotted with pale red and reddish-brown.

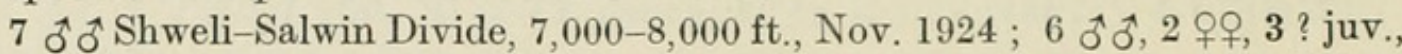
hills round Tengyueh, 6,000-8,000 ft., June and Dec. 1924; 3 우 ad., 1 우 juv. hills N.W. of Tengyueh, Sept. 1924.

\section{Saxicola torquata indica Blyth.}

2 ô $\widehat{o}$ ad. (freshly moulted) (Nos. 5593, 5594), 1 ô ad. (very worn) (No. 5243), 1 ㅇ ad., 1 ? (marked ㅇ) (No. 5883) round Tengyueh, 6,000 ft., June-Dec. 1924 ; 1 ㅇ hills N. of Tengyueh, 7,000 ft., Dec. 1924.

\section{Myiophoneus eugeniae Hume.}

In the description of the soft parts Forrest gives " iris blue-black," whereas in 1918 in his first collection he gives the iris as " dark crimson."

1 우 ? hills N. of Tengyueh, 8,000 ft., Aug. 1924; 1 ô, 1 ㅇ Shweli Valley,

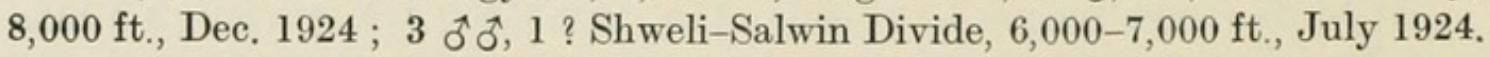

\section{Monticola solitarius pandoo (Sykes).}

1 ㅇ Shweli Valley, 6,000 ft., Dec. $1924 ; 1$ ㅇ ? Shweli-Salwin Divide, 6,000 ft., May 1924.

\section{Turdus eunomus Temm.}

3 ธิ రิ, 1 우 Shweli Valley, 7,000-9,000 ft., Nov.-Dec. 1924. 


\section{Turdus eunomus $\times$ Turdus naumanni.}

1 ㅇ Shweli Valley, 6,000-8,000 ft., Dec. 1924.

\section{Turdus obscurus Gm.}

2 ฮै ฮૈ, 6 웅 Shweli Valley, 7,000-8,000 ft., Dec. 1924.

\section{Turdus dissimilis Blyth.}

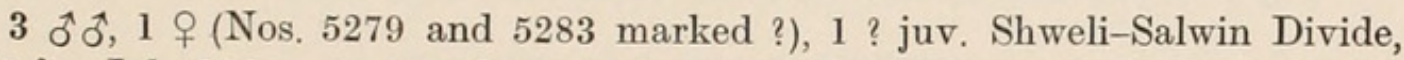
$8,000 \mathrm{ft}$., July 1924 ; 2 ô ô ad., 2 ôt juv. hills N. of Tengyueh, 7,000-8,000 ft., Nov.-Dec. 1924.

\section{Pomatorhinus ruficollis bakeri Har.}

1 ㅇ Tengyueh Valley, 6,000 ft., June 1924; 3 ô ô hills N. of Tengyueh, 7,000 ft., July and Nov. 1924; 1 ઈิ, 3 우우,4 ? hills round Tengyueh, 7,000-9,000 ft., June-Aug. and Nov. 1924; 4 ठิ ô Shweli Valley, 7,000-8,000 ft., Dec. 1924 ; 5 ธิ ธิ Shweli-Salwin Divide, 5,000-8,000 ft., July 1924.

\section{Pomatorhinus macclellandi odicus Bangs \& Phill.}

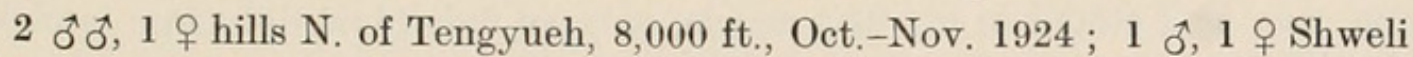
Valley, 7,000-9,000 ft., Dec. 1924 ; 3 우우 Shweli-Salwin Divide, 5,000-7,000 ft., July 1924.

\section{Ianthocincla squamata Gould.}

Ianthocincla squamata Gould, Proc. Zool. Soc. Lond. 1835, p. 48 (Himalayas).

1 ㅇ Shweli-Salwin Divide, 9,000 ft., Dec. 1924.

\section{Ianthocincla forresti Rothsch.}

At last Forrest has sent some more of this fine species.

1 ㅇ, 3 ? hills N.W. of Tengyueh, 9,000 ft., May 1924; 1 ${ }^{*}$ Shweli-Salwin Divide, 9,000 ft., Dec. 1924.

\section{Ianthocincla sannio (Swinh.).}

3 ô $\widehat{0}, 3$ 우우 Tengyueh Valley, 5,300 ft., April-June 1924; round Tengyueh, 5,000-7,000 ft., May-June and Nov.-Dec. 1924 ; 1 o, 1 ㅇ Shweli-Valley, 6,000$8,000 \mathrm{ft}$., Nov. 1924 .

72. Ianthocincla cineracea styani (Oust.).

1 o, 1 ㅇ ad. hills N.W. of Tengyueh, 7,000-8,000 ft., Sept. 1924 ; 1 우 ad., 1 ? juv. hills round Tengyueh, 5,300-7,000 ft., May-June 1924.

\section{Ianthocincla phoenicea wellsi (La Touche).}

Trochalopteron phoeniceum wellsi La Touche, Bull. B.O.C. vol, xlii, p. 15 (1921) (Mengtze).

2 ธิธิ, 3 우우 ? hills N. of Tengyueh, 8,000 ft., July-Aug. 1924. (Iris dark brown ; bill black-brown ; feet dark reddish-brown.)

Forrest's 5 specimens differ from La Touche's diagnosis in Nот having the 
crown and nape "much greener" than in ph. ripponi, but having it much greyer and the back more greenish. Therefore, it may be that, when we can compare a good series from the plains, with one from the high mountains, it will turn out that 2 forms of phoenicea inhabit Yunnan.

\section{Ianthocincla milnei sharpei (Rippon).}

Trochalopteron sharpei Rippon, Bull. B.O.C. vol. xii, p. 13 (1901) (Kentung State).

$2 \widehat{o} \widehat{o}^{\hat{t}}$ Shweli-Salwin Divide, 9,000-10,000 ft., Dec. 1924.

\section{Ianthocincla lanceolata lanceolata (Verr.).}

In my article on Forrest's first collection (Nov. ZooL., xxviii, p. 34, No. 111 (1921)) I referred all the 9 examples, there enumerated, to lanceolata bonvaloti (Oust.); whereas in my articles on the second and third collections (Nov. ZooL., vol. xxx, pp. 43, 44, and 256) I referred 7 examples to $l$. bonvaloti and 3 to l. lanceolata on account of differences in size. In the present collection there are 6 further examples, and Dr. Hartert very kindly went through our series of 18 in the Tring Museum and these 6 with me, and very carefully measured the wings of all 24. We came to the conclusion that Sharpe's difference between Oustalet's $l$. bonvaloti and his own $l$. yunnanensis, viz. black versus red moustachial line, was, as I stated in my first article, only an individual difference, and that the difference in size was sexual and also possibly a question of age, and we are therefore convinced that bonvaloti Oust. and yunnanensis Sharpe are pure synonyms of lanceolata lanceolata. We find the same differences in size in the allied species, viz. the gigantic waddelli and taivanum.

$1 \hat{\sigma}, 1$ ㅇ hills round Tengyueh, 6,000 ft., May $1924 ; 1$ ô, 1 ㅇ? ? hills N. of Tengyueh, 7,000 ft., Aug. 1924; 2 우 Shweli Valley, 8,000 ft., Dec. 1924.

\section{Stactocichla merulina merulina (Blyth).}

Garrulax merulina Blyth, Journ. As. Soc. Beng., vol. xx, p. 521 (1851) (Manipur).

This is also the first record of this very strange Laughing Thrush.

1 o hills N.W. of Tengyueh, 8,000 ft., Nov. 1924.

\section{Leiothrix luteus yunnanensis Rothsch.}

I distinguished and described this race from Forrest's first collection, and he did not send any Leiothrix in either the second or third collections. The present series of 9 examples amply confirms the distinctness of the subspecies. Quite lately 2 further Leiothrix have been described from China, one by Monsieur Delacour as astleyi from two cage birds, and one by Dr. Stresemann as kwangtungensis. Delacour's bird is mostly red, where luteus is yellow ; and Stresemann states that his bird is much richer in colour, therefore it is not improbable that both are the same, astleyi being changed in colour by captivity.

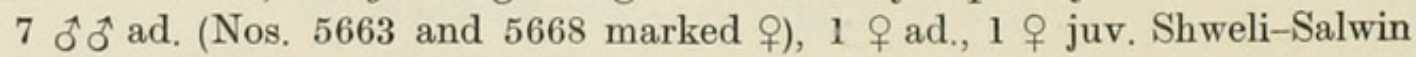
Divide, 9,000 ft., May and Nov. 1924.

\section{Schoeniparus dubius genestieri (Oust.).}

Forrest has sent this time 23 specimens of this species, 3 of which are young. In my article on his first collection (Nov. Zool, xxviii, p. 36, No. 121 
(1921)) I united Rippon's intermedius with it as a synonym ; but in my subsequent articles (Nov. ZooL., xxx) I was doubtful owing to some young birds. I now, however, have compared the large number at Tring (31 examples from Yunnan, S.W. China, and Bhamo) with these fresh 23 from Yunnan, and both Dr. Hartert and $I$ have been convinced that intermedius cannot be upheld.

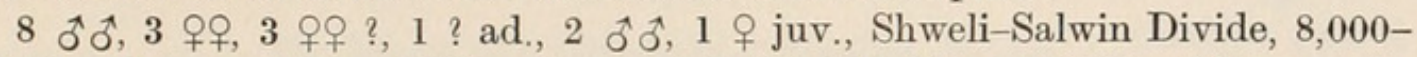
$9,000 \mathrm{ft}$., June and Nov. 1924; 2 ôt, 1 ㅇ, 2 ? hills N. and N.W. of Tengyueh, $8,000 \mathrm{ft}$., July and Sept.-Oct. 1924.

\section{Proparus vinipectus bieti Oust.}

1 ô Tengyueh Hills, 7,000 ft., Dec. 1924; 2 ô ô, Shweli-Salwin Divide, $7,000 \mathrm{ft}$., June 1924 .

\section{Brachypteryx cruralis cruralis Blyth.}

The single + sent has the white superciliary line absent, but this is also the case with some of our Indian examples. The single example from Mengtze, quoted as sinensis, may be that species, but the examples quoted by Baker as collected by Dr. Coltart in Assam are very doubtful, as we have several $q$ cruralis collected by him in Assam labelled sinensis, evidently on account of the lack of the superciliary line.

1 ㅇ Shweli-Salwin Divide, 6,000 ft., July 1924.

81. Leioptila pulchella coeruleotincta Rothsch.

1 ô Shweli-Salwin Divide, 7,000 ft., July 1924; 1 ? hills N. of Tengyueh, $7,000 \mathrm{ft}$., July 1924.

82. Leioptila desgodinsi (Dav. \& Oust.).

$1 \hat{\delta}, 2$ 우 Shweli Valley, 6,000-7,000 ft., Dec. 1924; $1 \hat{\jmath}$ Shweli-Salwin Divide, 8,000 ft., June $1924 ; 1 \hat{\delta}, 2$ 우 hills round and N. of Tengyueh, 6,0007,000 ft., Aug. and Nov.-Dec. 1924.

\section{Leioptila gracilis (McClell.).}

Hypsipetes gracilis McClelland, Proc. Zool. Soc. Lond. 1839, p. 159 (Assam).

This is the first record for Yunnan.

$1 \sigma^{*}$ ? hills N. of Tengyueh, 7,000 ft., Aug. 1924.

\section{Pseudominla castaniceps (Hodgs.).}

This ought to come before Leioptila by rights.

1 ơ hills N.W. of Tengyueh, 8,000 ft., Nov. 1924.

\section{Stachyridopsis ruficeps bhamoensis Har.}

1 ô, 2 우, 1 ? hills $N$. of and round Tengyueh, 7,000-8,000 ft., July-Sept.

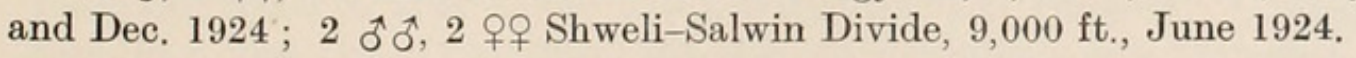

\section{Actinodura egertoni ripponi Ogil.-Grant.}

Actinodura ripponi Ogilvie-Grant, Ibis, 1907, p. 166 (Mount Victoria).

In my article on Forrest's first collection (Nov. Zool. xxviii, p. 38, No. 129 (1921)), I was misled by Bangs and Phillips quoting ramsayi and identified these 
birds with typical egertoni. On comparing the 17 specimens in the present collection I find that they certainly are not typical egertoni. They agree on the upper side with ripponi both in the more olive shade of the back and rump and in the more barred tail, and I do not venture to separate them from ripponi, although several of them have a greyer head. Below some are darker, but this is very variable.

1 우 ? Shweli Valley, 8,000 ft., Dec. 1924; 2 ิㅜㅅ, 2 우우, 1 ? Shweli-Salwin

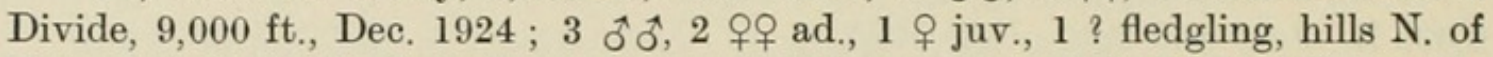
Tengyueh, 8,000 ft., June-Aug. 1924; 1 సै, 2 우, 1 q juv., hills N.W. of Tengyueh, $8,000 \mathrm{ft}$., June 1924.

\section{Minla ignotinca Hodgs.}

When I wrote the article on the first collection (Nov. Zool. xxviii) I expressed the opinion that $M$. jerdoni Verr. was identical with ignotinca. Since then a considerable amount of further light has been thrown on the subject and many more specimens have come to hand. I received a small lot of birds from the late Charles Oberthur, the great lepidopterist, which were said to have come from Cochin-China, but I do not believe the locality is at all certain. In this series is a MALE Minla with deep-red edges to the primaries, but with an olive back, and otherwise exactly like the figure of $M$. jerdoni in the Nouvelles Archives Mr. La Touche says in his description of his new $M$. ignotinca mariae that the description of the edging of the primaries in the Oiseaux de la Chine does not agree with his Mengtze birds; this, however, is an error, for if you examine the Indian birds some have the edges entirely red, some red tipped with yellow, and some half-red, half-yellow, so that this is an absolutely negligible character. In view of my supposed Cochin-China jerdoni, and Mr. La Touche's and Bangs and Phillips' Mengtze series of 14 examples, I am convinced that $i$. mariae and jerdoni are very closely allied and that we have three forms of Minla, viz. ignotinca ignotinca Hodgs, from Himalayas, Assam, and down to Manipur and the higher mountains of Western Yunnan, ignotinca jerdoni Verr. from Chenton in China and ign. mariae in Eastern Yunnan. All the series of 18 examples in the present collection are $i$. ignotinca. Bangs and Phillips and La Touche expressly emphasise the fact that their birds from Mengtze are very bright yellow below, and treat this as a distinguishing character of $i$. jerdoni; but in this they are wrong, for the original $i$. jerdoni is not yellow, and all my series of $i$. ignotinca from N.W. Yunnan and those from Mengtze are very yellow. I have now received 2 further true jerdoni, and these are white below.

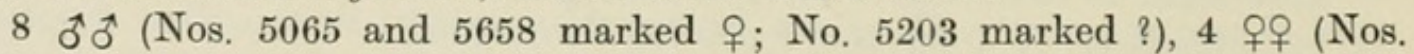

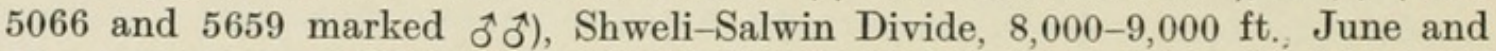
Nov. 1924 ; 3 ธิธَ (No. 5378 marked ?), 2 우우 hills N. of Tengyueh, 8,000 ft., July-Aug. and Nov. 1924; 1 ㅇ (marked ?) hills round Tengyueh, 6,000 ft., June 1924.

\section{Siva strigula yunnanensis Rothsch.}

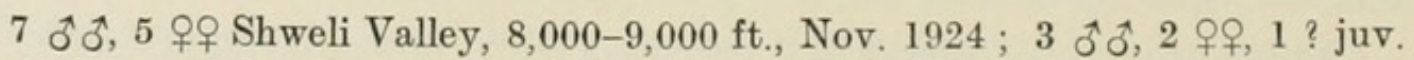
Shweli-Salwin Divide, 8,000 ft., June-July 1924. 
89. Siva cyanuroptera wingatei Grant.

$1 \hat{\jmath}$, 1 q hills N. of Tengyueh, 7,000 ft., Aug. 1924; 1 ㅇ Shweli Valley,

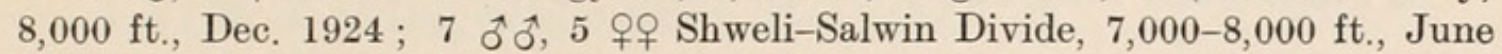
and Nov. 1924.

\section{Pteruthius melanotis melanotis Hodgs.}

Forrest has at last sent some more of this little bird. The $\hat{\sigma}$ proves to be quite indistinguishable from $m$. melanotis, and the of proves that the former 우 were somewhat aberrant in the extent of brown on the throat, as this $O$ is in that respect almost similar to Sikkim 우옹

$1 \hat{\sigma}$ hills N. of Tengyueh, 8,000 ft., Oct. 1924; 1 오 (marked ô) Shweli Valley, 7,000 ft., Dec. 1924.

\section{Pteruthius aeralatus ricketti Grant.}

$1 \hat{\jmath}, 2$ 우 Shweli-Salwin Divide, 9,000 ft., Dec. 1924; 1 ô, 1 오 Shweli Valley, 9,000 ft., Dec. 1924 ; 2 ઠิ ठิ, 2 우 hills N.W. of Tengyueh, 8,000-9,000 ft., Sept. 1924.

\section{Suya superciliaris superciliaris Anderson.}

1 q hills S. of Tengyueh, 7,000 ft., Nov. 1924; 2 우 hills N. of Tengyueh,

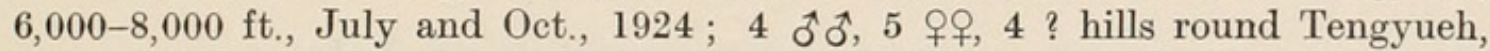
5,000-6,000 ft., May-July and Sept. 1924; 1 우 Tengyueh, 7,000 ft., Sept. 1924.

\section{Suya parvirostris La Touche.}

The 3 specimens in the present collection are in good plumage.

3 ? hills round Tengyueh, 5,000-6,000 ft., May and July, 1924.

94. Yuhina gularis griseotincta Rothsch.

3 ธิธૈ, 4 우우 Shweli-Salwin Divide, 8,000-9,000 ft., June and Nov. 1924.

95. Yuhina flavicollis rouxi (Oust.).

2 우, 1 ? hills N.W. of Tengyueh, 8,000-9,000 ft., Oct. and Dec. $1924 ; 4$ ơ $\widehat{o}$, 1 옹 Shweli-Salwin Divide, 9,000 ft., June and Nov. 1924.

\section{Yuhina diademata diademata.}

4 우 Shweli-Salwin Divide, 7,000-8,000 ft., June and Nov. 1924.

\section{Alcippe nipalensis yunnanensis Har.}

$1 \hat{\delta}, 1$ q Shweli-Salwin Divide, 7,000 ft., Oct. $1924 ; 1 \hat{\sigma}$ hills N.W. of Tengyueh, 9,000 ft., Nov. 1924; 3 ठิ ठิ, 6 우우 hills N. of Tengyueh, 7,000-8,000 ft., July-Aug. and Oct.-Dec. $1924 ; 14$ ô ô, 16 우우 hills round Tengyueh, 6,0008,000 ft., May-July and Oct. 1924.

\section{Franklinia gracilis (Franvl.).}

1 ? hills round Tengyueh, 6,000 ft., July 1924. 
99. Prinia inornata exter Thayer \& Bangs.

1 ? hills round Tengyueh, 5,000-6,000 ft., July 1924.

100. Phylloscopus subaffinis (Grant).

1 ㅇ Shweli Valley, 8,000 ft., Dec. 1924.

101. Phylloscopus fuscatus (Blyth).

1 hills N. of Tengyueh, 7,000 ft., Dec. 1924.

102. Phylloscopus davisoni (Oates).

2 ธิธో రో, 3 우우 hills round Tengyueh, 5,000-9,000 ft.

103. Phylloscopus superciliosus superciliosus (Gm.).

Motacilla superciliosa Gmelin, Syst. Nat., vol. i, p. 975 (1788) (ex Latham, Gen. Syn. ii, p. 549, “Russia").

1 o hills round Tengyueh, 7,000 ft., Dec. 1924.

104. Phylloscopus lugubris Blyth.

1 ઈิ, 2 우우 hills round Tengyueh, 5,000-9,000 ft., Oct.-Nov. 1924.

105. Cryptolopha burkii tephrocephala (Anders.).

$1 \hat{\delta}, 1$ ? hills round Tengyueh, 6,000-8,000 ft., June-July $1924 ; 1$ ô, 1 우 hills S. of Tengyueh, 7,000 ft., Oct. 1924.

\section{Culicicapa ceylonensis (Swains.).}

3 ธิธิ, 3 우 Shweli-Salwin Divide, 6,000-8,000 ft., June and Nov. 1924 ; 1 \& hills round Tengyueh, 6,000-8,000 ft., Nov. 1924.

\section{Chelidorynx hypoxantha (Blyth).}

1 ô, 1 우 hills round Tengyueh, 8,000 ft., June 1924.

108. Muscicapa blythi Rothsch.

3 ổ ổ ad., 1 ổ juv. (Nos. 4543, 4544 marked ㅇ) Tengyueh Valley, 5,500 ft.,

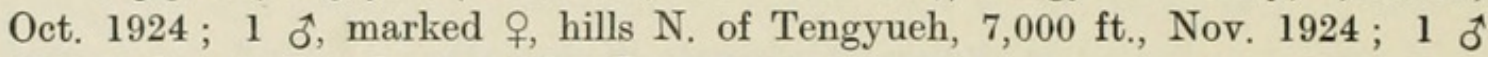
Shweli-Salwin Divide, 8,000 ft., June 1924.

\section{Muscicapa parva albicilla (Pall.).}

2 우우 ad. (No. 5549 marked $\left.{ }^{\uparrow}\right), 1$ ㅇ juv. hills N. of Tengyueh, 7,000-8,000 ft., Oct. 1924.

110. Muscicapa thalassina thalassina Swains.

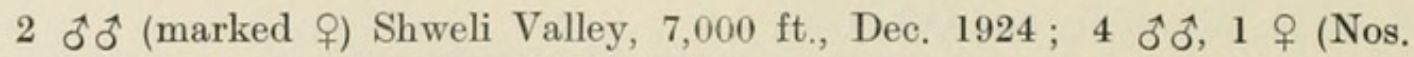
5437 and 5441 marked () hills N.W. of Tengyueh, 7,000-8,000 ft., Aug.-Sept. $1924 ; 4$ ธิ ô ad. (No. 5071 marked ?), 1 ? juv. hills round Tengyueh, 6,000 ft., May-June, 1924. 
111. Anthipes laurentei La Touche.

Anthipes laurentei La Touche, Bull. B.O.C., vol. xlii, p. 15 (1921) (Loukouchai).

1 ô hills N. of Tengyueh, 7,000 ft., Nov. 1924.

\section{Niltava sundara Hodgs.}

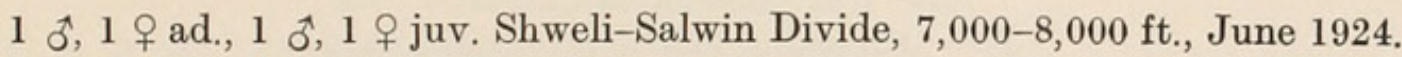

\section{Niltava grandis (Blyth).}

$1 \delta^{\hat{t}}$ ad. hills N. of Tengyueh, 9,000 ft., Aug. 1924; 1 ? juv. hills round Tengyueh, 7,000 ft., Aug. 1924; 1 ô ad. Shweli-Salwin Divide, 6,000 ft., June 1924.

\section{Tchitrea paradisi affinis "Hay" Blyth.}

Journ. As. Soc. Beng., vol. xv, p. 292 (1846) (Malay Peninsula and Tenasserim).

1 ô juv. hills N. of Tengyueh, 7,000 ft., Oct. 1924.

(For some unaccountable reason Mr. La Touche has applied the name incii Gould to this kind, whereas true incii is a purple-backed species, never white.)

\section{Rhipidura albicollis albicollis (Vieill.).}

3 ô ô, 4 우 Tengyueh Valley, 5,500-7,000 ft., Oct.-Dec. 1924; 1 ? ShweliSalwin Divide, 8,000 ft., Nov. 1924.

\section{Pericrocotus speciosus speciosus (Lath.).}

Mr. La Touche, in 1921 (Bull. B.O.C., xlii, p. 54) described a speciosus baleri from S.E. Yunnan, giving as distinctions from speciosus fokhiensis the red on the central rectrices in the $\delta \widehat{o}$ and the darker colour of the back in the 우우; from speciosus speciosus he said it differed by the scarlet-, not orange-red. Now, in the same year, but somewhat earlier, I identified the 3 birds sent by Forrest in his first collection as speciosus speciosus, and, moreover, at Tring I have 2 males from the same place in the Sikkim Himalayas, one of which is orange-, the other scarlet-red. I therefore am obliged to sink Mr. La Touche's sp. bakeri as a synonym of $s p$. speciosus.

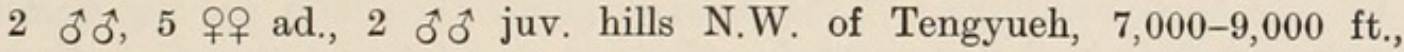
Sept. 1924.

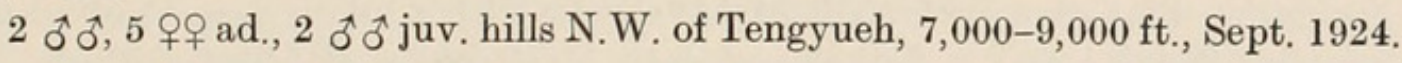

\section{Pericrocotus brevirostris ethelogus Bangs \& Phill.}

I am still very much in doubt as to the status of this form and neglectus Hume, and the present series does nothing to clear up my difficulties-in fact, only increases the doubts.

1 ô ad., 2 우 ad., 1 juv. hills round Tengyueh, 6,000 ft., June and Nov. 1924 ; 1 ô ad. Tengyueh Valley, 7,000 ft., Dec. 1924.

\section{Pericrocotus sp. ?}

This is a young bird agreeing in colour with a young bird at Tring of solaris, except that the yellow in the wing is more orange, but it has a gigantic bill almost as large as in speciosus.

1 ㅇ ? hills round Tengyueh, 6,000 ft., June 1924. 


\section{Pericrocotus solaris solaris Blyth.}

Pericrocotus solaris Blyth, Journ. As. Soc. Bengal, vol. xv, p. 310 (1846) (Darjeeling).

This is the first record for Yunnan.

1 \& Shweli Valley, 7,000 ft., Dec. 1924.

\section{Graucalus macei siamensis Baker.}

Graucalus macei siamensis Stuart Baker, Bull. B.O.C., vol. xxxviii, p. 69, No. 4 (1918) (Mi-Nam, Kabun).

I determined the only example, a young bird, sent by Forrest in his first collection, as macei macei, but as I now have an adult + I perceive that the N.W. Yunnan form belongs to $m$. siamensis.

1 ㅇa․ (marked ô) hills N. of Tengyueh, 8,000 ft., Dec. 1924.

\section{Campephaga melachistos melachistos (Hodgs.).}

Volvocivora melachistos Hodgson, Ind. Rev., vol, i, p. 328 (1837) (Nepal).

Stuart Baker unites avensis (melanoptera) as a subspecies to melachistos, but I am convinced he is wrong, because they both occur together in the Tengyueh district.

1 ô, 1 ㅇ hills N.W. of Tengyueh, 8,000 ft., Sept. 1924.

\section{Spizixos canifrons Blyth.}

2 ô $\widehat{0}, 2$ 우 hills N. of Tengyueh, 9,000 ft., Aug. 1924.

\section{Microscelis concolor (Blyth).}

Dr. Stresemann, after examining a big series of concolor, leucocephalus, perniger, and sinensis, has come to the conclusion that the dark birds and the white-headed ones are the same species. In addition, founding his observations on the fine Chinese material of Dr. Weigold, he declares that the glossy black "Formenkreis" of perniger with its various races, sinensis, etc., and the group of concolor, are merely colour phases of the same species. This he emphasises, because he has examples of the perniger glossy type with varying degrees of white heads as in the leucocephalus phase of concolor, and, therefore, draws the conclusion that concolor is a dimorphic species with a bright deep black phase $=$ perniger Swinh., and a dull, more slaty black phase = concolor Blyth. The present 6 specimens all belong to the concolor phase, 3 adults and 1 young being uniform dark typical concolor examples, 1 a white-headed leucocephalus, and the last an intermediate between leucocephalus and concolor. The truth is that in Setchuan only white-headed leucocephalus occur, while in Hainan and Formosa only black-headed ones; in Yunnan and on the coast mixed are found.

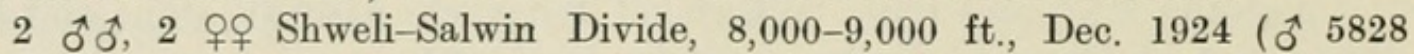
complete leucocephalus, ô 5831 intermediate) ; 1 ㅇ, 1 ? juv. hills N. of Tengyueh, 8,000 ft., Aug. 1924.

\section{Alcurus striatus Blyth.}

The 9 specimens sent in the present collection show a wing measurement

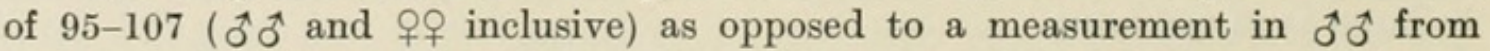
Assam and Burma of 97-107, whereas Yunnan (including former collections.) 
ô $\sigma^{A}$ only vary from 99 to 109 , thus proving that Bangs and Phillips's st. paulus has no existence in fact.

4 ธิ ฮิ, 5 우 hills N. of Tengyueh, 9,000 ft., July-Aug. 1924.

\section{Pycnonotus xanthorhous And.}

1 ô, 3 우 hills round Tengyueh, 5,000-8,000 ft., June and Aug. 1924; 1 ㅇ, 2 ? Tengyueh Valley, 5,300 ft., July 1924 ; 1 q (? ơ a.) Shweli Valley, 6,000 ft., Nov. 1924.

\section{Molpastes burmanicus (Sharpe).}

6 ธิ ฮิ, 3 우, 2 ? hills round Tengyueh, 6,000 ft., July, Sept., and Dec. 1924 ; 1 ๙ 1 i hills N. of Tengyueh, 7,000 ft., Aug. $1924 ; 1$ ? nestling hills S. of Tengyueh, $7,000 \mathrm{ft}$., Nov. 1924.

127. Iole maclellandi similis Rothsch.

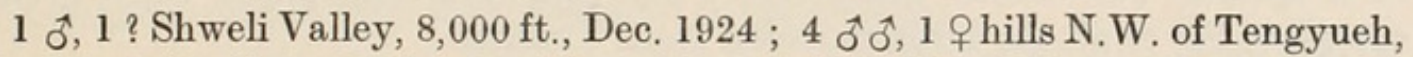
7,000-8,000 ft., Oct. 1924 ; 3 ธิธิ, 6 우, 1 ? hills N. of Tengyueh, 8,000 ft., Aug. 1924.

\section{Chloropsis hardwickii Yard. \& Selby.}

2 ơ $\sigma^{\widehat{T}}$ hills N. of Tengyueh, 7,000 ft., Aug. 1924; 1 q hills E. of Tengyueh, 9,000 ft., Dec. 1924.

\section{Lanius collurioides siamensis Gyldenst.}

Lanius collurioides siamensis Gyldenstolpe, Orn. Monatsb., vol. xxiv, p. 28 (1916) (Koh Lak).

The fine adult $\delta$ is undoubtedly this race, and so are the young birds of the first collection; the adult $\hat{\sigma}$ is easily distinguished by the pale back and wing edgings, and also by the white lores and superciliary markings. I had identified the former 3 specimens as collurioides collurioides.

1 ㅇ ad. Shweli Valley, 7,000 ft., Dec. 1924.

\section{Lanius cristatus cristatus Linn.}

2 ơ ơ juv. round Tengyueh, 6,000 ft., Dec. 1924.

\section{Lanius shach tephronotus (Vig.).}

2 우 ad. Shweli Valley, 6,000-8,000 ft., Dec. 1924; 1 우 ? juv. round Tengyueh, 6,000 ft., Nov. 1924.

\section{Lanius nigriceps nigriceps (Frankl.).}

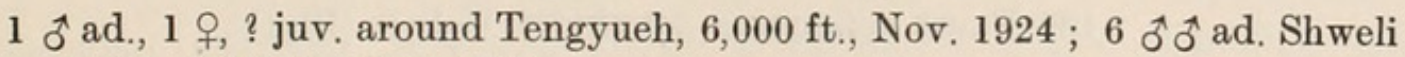
Valley, 6,000-8,000 ft., Dec. 1924.

\section{Paradoxornis guttaticollis A. Dak.}

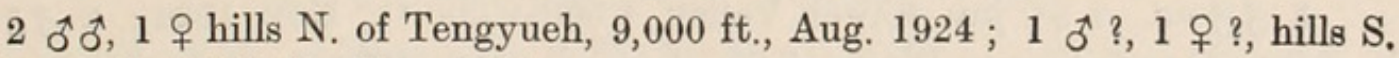
of Tengyueh, 7,000 ft., Dec. 1924. 


\section{Paradoxornis brunnea (Anders.).}

There is a certain amount of doubt about the species and subspecies of the webbiana group which arises owing to the absence or presence in varying degrees of the striping on the throat in the same locality. Also the degree of vinaceous or chestnut coloration on the cheeks in the various races of webbiana. The exact status of brunnea is a great puzzle; it undoubtedly has the cheeks almost uniform in chestnut colouring with the crown, whereas my webbiana ricketti has a much paler, almost white throat heavily striped and has the cheeks vinaceous and striped like the throat-in fact, except that it has the throat whiter and the crown and nape much darker chestnut it is very close to webbiana styani. The chief difficulty arises from the fact that my ricketti and brunnea occur together in N.W. Yunnan. One great distinction between ricketti and brunnea is that the latter has the breast and half the abdomen vinaceous, which is not the case in ricketti and styani, and which in the other races of webbiana only goes as far down as the breast at the outside. I shall therefore, for the present, treat brunnea as a species, and decide definitely in my proposed final paper when giving a complete list of all the birds recorded from Yunnan.

5 ฮิ రิ, 6 우우 Tengyueh Valley, 5,500-6,000 ft., June and Sept.-Oct. 1924 ;

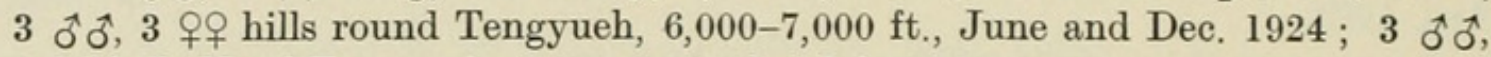
2 우 hills N. of Tengyueh, 6,000-7,000 ft., July 1924.

\section{Paradoxornis poliotis poliotis (Blyth).}

Suthora poliotis Blyth, Journ. As. Soc. Beng., vol, xx, p. 522 (1851) (Cherrapunji).

This seems to be the first record for Yunnan. The two birds appear to be not quite adult, so I do not venture to separate them from $p$. poliotis, but the crown is decidedly more olive, less rufous than in my 4 Burmese $p$. poliotis.

1 ô, 1 o hills N.W. of Tengyueh, 9,000 ft., Sept. 1924.

\section{Aegithaliscus concinnus talifuensis Ripp.}

1 ? Shweli Valley, 10,000 ft., Dec. 1924; $1 \hat{\sigma}$ hills N. of Tengyueh, 8,000$9,000 \mathrm{ft} .$, Nov. $1924 ; 1 \hat{\delta}, 1$ i hills N.W. of Tengyueh, Nov. $1924 ; 1+$ hills round Tengyueh, 7,000 ft., July 1924.

137. Parus monticolus yunnanensis La Touche.

1 ô hills round Tengyueh, 6,000 ft., Dec. 1924 ; 1 ô hills N. of Tengyueh, $8,000 \mathrm{ft}$., Dec. 1924.

138. Parus major tibetanus Hart.

1 o Tengyueh Valley, 7,000 ft., Dec. 1924; 1 ô hills N. of Tengyueh, 8,000 ft., Dec. 1924.

139 Parus spilonotus subviridis Tickell (Blyth).

Parus subviridis Tickell (Blyth), Journ. As. Soc. Beng., vol, xxiv, p. 265 (1855) (Tenasserim).

I wrongly identified the two examples of this bird in the first collection as sp. spilonotus.

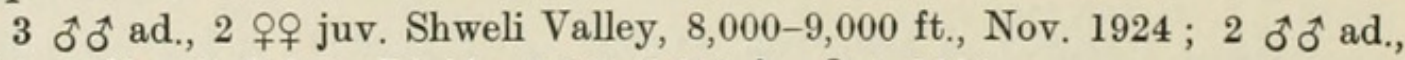
1 ô juv. Shweli-Salwin Divide, 7,000-8,000 ft., Oct. 1924. 
140. Sitta europaea nebulosa La Touche.

$1 \hat{\delta}, 1$ 우 ? hills round Tengyueh, 5,000-8,000 ft., June 1924; 1 ô Shweli Valley, 9,000 ft., Dec. 1924.

\section{Zosterops simplex Swinh.}

This bird has usually been treated as a subspecies of $Z$. palpebrosa, as I also have done, but it is resident in N.W. Yunnan with a true palpebrosa form and must be treated as a distinct species. In S.E. Yunnan Mr. La Touche records two different birds as Zosterops palpebrosa subsp. ; the first is evidently a simplex form and the second a palpebrosa form.

1 ㅇ, 1 ? hills round Tengyueh, 7,000 ft., June $1924 ; 1$ ㅇ, 1 ? hills N. of Tengyueh, 7,000 ft., June 1924; 3 ๙ิ ô, 3 우 Shweli-Salwin Divide, 6,000-8,000 ft., Nov. 1924.

142. Zosterops palpebrosa elwesi Baker.

Zosterops palpebrosa elwesi Stuart Baker, Ibis, 1922, p. 144 (Sikkim).

This is a new record for Yunnan; as it had hitherto been confused with simplex.

1 ô, 2 우아 hills N. of Tengyueh, 7,000 ft., June 1924; 1 ㅇ hills S. of Tengyueh, 8,000 ft., Dec. 1924; 2 우, 1 ? Shweli-Salwin Divide, 6,000-8,000 ft., Nov. 1924.

\section{Dicaeum ignipectus ignipectus (Blyth).}

1 ô ad. Shweli Valley, 9,000 ft., Nov. 1924 ; 1 juv. Shweli-Salwin Divide, $9,000 \mathrm{ft}$., June 1924 .

\section{Dicaeum minullum olivaceum Wald.}

3 우, 1 ? Shweli-Salwin Divide, 9,000 ft., June 1924; 1 hills round Tengyueh, 7,000 ft., June 1924 ; 1 ㅇ hills N.W. of Tengyueh, 8,000-9,000 ft. , Oct. 1924 .

\section{Aethopyga ignicauda exultans Baker.}

1 ㅇ hills N.W. of Tengyueh, 9,000 ft., Dec. 1924.

\section{Aethopyga dabryii (Verr.).}

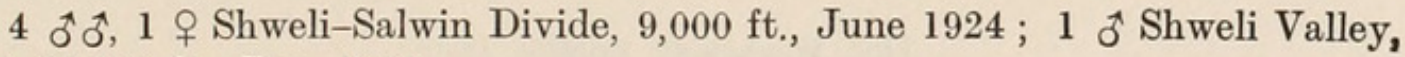
9,000-10,000 ft., Dec. 1924.

\section{Aethopyga nipalensis nipalensis (Hodgs.).}

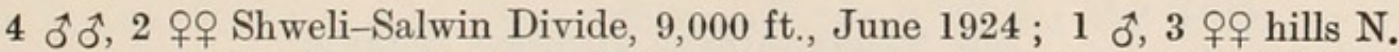
of Tengyueh, 9,000 ft., July-Aug. 1924; 3 ธิ ठิ ad., 1 ธิ juv. hills N.W. of Tengyueh, 8,000-9,000 ft., Oct. 1924.

148. Arachnothera magna magna (Hodgs.).

1 ot hills N.W. of Tengyueh, 9,000 ft., Sept. 1924. 
149. Motacilla alba hodgsoni Blyth.

2 ơ $\widehat{o}$ Tengyueh Valley, 5,500 ft., Nov. 1924; 1 ơ juv. round Tengyueh, 6,000 ft., Sept. 1924.

150. Motacilla alba leucopsis Gould.

3 ơ ô, 2 우우 Tengyueh Valley, 6,000 ft., Dec. 1924.

151. Motacilla boarula melanope Pall.

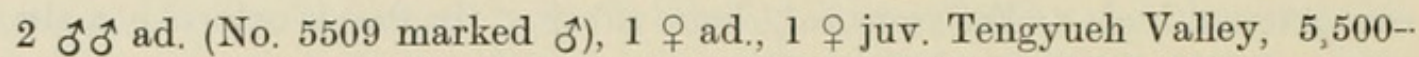
6,000 ft., Nov. 1924; 1 우 (marked ơ) Shweli Valley, 7,000 ft., Dec. 1924.

\section{Dendronanthus indicus (Gm.).}

Motacilla indica Gmelin, Syst. Nat., vol. i, p. 962 (1788) (ex Sonnerat and Latham, India).

This is, I believe, the first record for N.W. Yunnan, but La Touche records it from Mengtsz, and so does Collingwood Ingram.

1 ㅇ Tengyueh Valley, 6,000 ft., Sept. 1924.

153. Anthus berezowskii yunnanensis Uch. \& Kur.

2 ธิ ชิ, 2 우우 Tengyueh Valley, 5,500 ft., Nov. 1924.

\section{Anthus roseatus Blyth.}

The f from N. of Tengyueh (No. 5887) has the spotting on the under-surface much heavier than any in our long series at Tring.

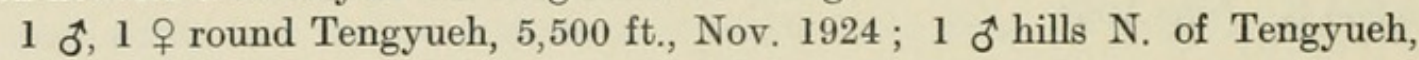
7,000 ft., Dec. 1924.

\section{Anthus richardi richardi Vieill.}

1 ㅇ hills round Tengyueh, 6,000 ft., Dec. 1924.

156. Alauda arvensis japonica Temm. \& Schleg.

1 우 hills round Tengyueh, Dec. 1924.

\section{Melophus melanicterus (Gm.).}

1 ㅇ juv. hills S. of Tengyueh, 6,000 ft., Oct. 1924.

\section{Emberiza pusilla Pall.}

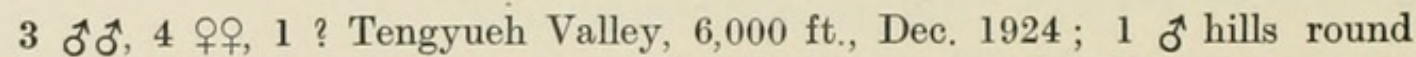
Tengyueh, 7,000 ft., Oct. 1924; 2 ơ ơ Shweli Valley, 7,000 ft., Nov. 1924.

\section{Passer rutilans intensior Rothsch.}

Mr. Kinnear has compared a huge series ranging from Cashmere to Yunnan, consisting of 194 specimens, in the Tring and British Museums (34 Tring, 160 British Museum), and came to the conclusion that rutilans cinnamomeus and rutilans debilis were the same, and that my rutilans intensior showed differences in the darker colour of the 우오. The two freshly moulted 우 now to hand do 
not bear this out, but the freshly moulted $\sigma^{t} \sigma^{t}$ show some differences, so I shall retain the name at all events till my final paper.

2 ธै $\widehat{0}, 2$ 우 hills round Tengyueh, 6,000-8,000 ft., June and Dec. 1924 ; 1 đิ, 1 오 Shweli-Salwin Divide, 8,000 ft., Nov. 1924.

\section{Haematospiza sipahi (Hodgs.).}

Corythus sipahi Hodgson, Asiat. Research., vol. xix, p. 151 (1836) (Nepal).

In my article on the first collection of Forrest I adopted Hartert's view that the correct name of this bird was indica Gmelin. This view is, however, not accepted by most ornithologists, and Hartert himself now says that as there is a slight doubt, the name of Hodgson is safer.

1 ơ Shweli-Salwin Divide, 9,000 ft., June 1924.

\section{Pyrrhula nipalensis ricketti La Touche.}

Pyrrhula ricketti La Touche, Bull. B.O.C., vol. xvi, p. 21 (1905) (Mts. of N.W. Fokien).

This is the first record for N.W. Yunnan. The 2 specimens now to hand are

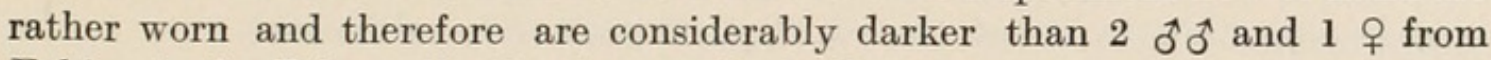
Fokien in the Tring collection in very fresh plumage.

1 ot, 1 o hills N. of Tengyueh, 9,000 ft., Aug. 1924.

\section{Carduelis ambiguus (Oust.).}

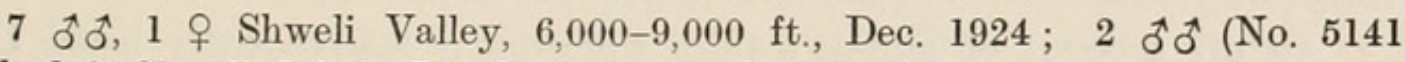
marked f) Shweli-Salwin Divide, 8,000 ft., July 1924.

\section{Mycerobas melanozanthus (Hodgs.).}

1 đ juv. hills N.W. of Tengyueh, 8,000-9,000 ft., Nov. 1924.

\section{Munia atricapilla atricapilla (Vieill.).}

1 ơ Shweli-Salwin Divide, 8,000 ft., July 1924.

165. Munia punctulata topela Swinh.

3 ๙ิ $\widehat{0}, 9$ 우우, 2 ? ad., 1 ô juv. hills round Tengyueh, 6,000 ft., May-July and Dec., $1924 ; 2$ ? hills N. of Tengyueh, 7,000 ft., June $1924 ; 1$ ऽै, 1 ㅇ, 1 ? ad., 1 우 ? juv. hills S. of Tengyueh, 6,000-8,000 ft., Nov.-Dec. $1924 ; 1$ ô juv. Shweli Valley, 7,000 ft., Dec. 1924.

\section{Oriolus indicus tenuirostris Blyth.}

$1 \widehat{\delta}$ ad., 1 ㅇ juv. hills round Tengyueh, 5,000-8,000 ft., May $1924 ; 1$ ๙ै, 1 q ad. hills N. of Tengyueh, 7,000 ft., Dec. $1924 ; 1$ o ad. hills N.W. of Tengyueh, $8,000 \mathrm{ft}$., Oct. 1924 ; 1 đิ ad. Shweli-Salwin Divide, 8,000 ft., Dec. 1924.

\section{Oriolus trailli (Vig.).}

1 o hills N. of Tengyueh, 8,000 ft., July 1924.

\section{Dicrurus hottentotta (Linn.).}

2 ơ $\sigma^{*}$ hills N.W. of Tengyueh, 7,000 ft., Sept, 1924. 
169. Dicrurus macrocercus cathoecus Swinh.

1 of, 1 ㅇ ad., 1 ? juv. round Tengyueh, 5,000-6,000 ft., May-June 1924 ; 1 ? juv. Tengyueh Valley, 5,300 ft., July $1924 ; 1$ ô N.W. of Tengyueh, 7,000 ft., Sept. 1924.

\section{Dicrurus leucophoeus nigrescens Oates.}

1 ô, 1 \& Tengyueh Valley, 5,000-6,000 ft., July 1924; 2 ? round Tengyueh, 5,000-6,000 ft., June and Dec. 1924; $1 \hat{\sigma}$ hills N.W. of Tengyueh, 6,000 ft., Oct. $1924 ; 4$ ธิ ठิ, 1 우 Shweli Valley, 6,000-8,000 ft., Dec. 1924.

171. Chaptia aenea (Vieill.).

Dicrurus aeneus Vieillot, Nouv. Dict. d'Hist. Nat., vol. ix, p. 586 (1817) (Bengal).

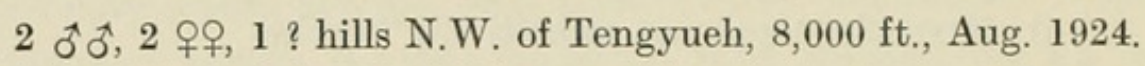

172. Bhringa remifer (Temm.).

Edolius remifer Temminck, Planch. Col., vol. iii, pl. 178 (1823) (Java and Sumatra).

1 ㅇ hills N.W. of Tengyueh, 7,000 ft., Sept. 1924.

173. Acridotheres grandis Moore.

Acridotheres grandis Moore, Cat. B. Mus. E.T. Co., vol, ii, p. 537 (1856) (Sumatra !).

In my account of Forrest's third collection I inadvertently listed the $f$ " No. 1381 round Tengyueh, 5,000-6,000 ft., March 1922 " as A. cristatellus.

1 ô, 1 ? Tengyueh Valley, 5,300 ft., July 1924.

174. Acridotheres cristatellus cristatellus (Gm.).

1 ô, 1 o Shweli Valley, 6,000 ft., Dec. 1924.

175. Nucifraga caryocatactes yunnanensis Ingr.

2 đึ రో, 2 우우 Shweli Valley, 8,000-10,000 ft., Dec. 1924.

176. Urocissa erythrorhyncha erythrorhyncha (Gm.).

2 ô $\widehat{x}$ Shweli Valley, 6,000-9,000 ft., Nov, 1924; 1 ô Tengyueh Valley, $6,000 \mathrm{ft}$., June 1924.

177. Dendrocitta formosae himalayensis Blyth.

Mr. E. C. Stuart Baker, in his Fauna of British India Birds, vol. i, p. 52, puts himalayensis down as a subspecies of sinensis Lath. $\mathrm{He}$ has completely overlooked the fact that Dr. Stresemann already in 1913, Ornith. Monatsb., vol. xxi, p. 9, had shown that the name Corvus sinensis Gm. ex Lath. could not be used as applying to the Dendrocitta from China, as the diagnosis is totally different, and therefore renamed the bird Dendrocitta formosae sinica. Mr. Baker further complicates matters by saying that his sinensis (non Gmelin) = sinica of Stresemann had an entirely PALE GREY tail with No black tip, whereas sinensis $=$ sinica has in reality the wHOLE of the tail BLACK. A great disadvantage to students in Mr. Baker's book is that, as in the present instance, when he is 
dealing with Indian subspecies of extra-limital species, he never gives the quotation of the extra-limital typical race.

1 ô ad., 1 ô ?, 1 o ? juv. ? Shweli-Salwin Divide, 9,000 ft., May and Dec.

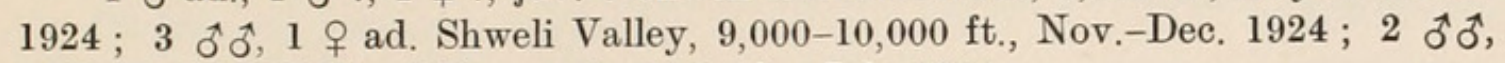
2 우 ad. hills N.W. of Tengyueh, 7,000 ft., July 1924.

\section{Pica pica serica Gould.}

Pica serica Gould Proc. Zool. Soc. Lond., 1845, p. 2 (Amoy).

2 ธิ $\widehat{0}, 4$ 우 Tengyueh Valley, 6,000-7,000 ft., Dec. $1924 ; 1$ ô round Tengyueh, 6,000 ft., Dec. 1924.

\section{Corvus coronoides intermedius Adams.}

1 o Tengyueh Valley, 6,000 ft., Dec. 1924.

The fourth collection consists of 916 skins of 176 species and subspecies, of which 29 had not been sent before. 


\section{$2 \mathrm{BHL}$ Biodiversity Heritage Library}

1925. "On a fourth collection of Birds made by Mr. George Forrest in North-western Yunnan." Novitates zoologicae : a journal of zoology in connection with the Tring Museum 32, 292-313.

https://doi.org/10.5962/bhl.part.4509.

View This Item Online: https://www.biodiversitylibrary.org/item/22601

DOI: https://doi.org/10.5962/bhl.part.4509

Permalink: https://www.biodiversitylibrary.org/partpdf/4509

\section{Holding Institution}

Natural History Museum Library, London

\section{Sponsored by}

Natural History Museum Library, London

\section{Copyright \& Reuse}

Copyright Status: In copyright. Digitized with the permission of the rights holder.

Rights Holder: The Trustees of the Natural History Museum, London

License: http://creativecommons.org/licenses/by-nc-sa/4.0/

Rights: http://biodiversitylibrary.org/permissions

This document was created from content at the Biodiversity Heritage Library, the world's largest open access digital library for biodiversity literature and archives. Visit BHL at https://www.biodiversitylibrary.org. 